\title{
Studies on Gastric Mucoproteins
}

\author{
THE PRODUCTION OF RADIOACTIVE MUCOPROTEINS BY \\ PIG GASTRIC MUCOSAL SCRAPINGS IN VITRO
}

\author{
By D. SNARY and A. ALLEN \\ Department of Biochemistry, University of Newcastle upon Tyne, Newcastle upon Tyne NE1 7RU, U.K.
}

(Received 29 November 1971)

\begin{abstract}
1. Optimum conditions, including the effect of media of different $\mathrm{pH}$ values, were determined for the incorporation of radioactive precursors into mucoproteins by pig gastric mucosa in vitro. 2 . Mucosal scrapings incorporated radioactivity from $\left[\mathrm{U}-{ }^{14} \mathrm{C}\right]$ glucose and from $\left[\mathrm{G}-{ }^{3} \mathrm{H}\right]$ threonine or $\left[\mathrm{G}-{ }^{3} \mathrm{H}\right]$ serine solely into the carbohydrate and protein portions respectively of the mucoprotein molecules. 3 . Of the radioactive mucoprotein $22 \%$ was water-soluble and up to $80 \%$ of the remainder was soluble in other solvents. 4. Pronase was the most successful proteolytic enzyme tested for making the mucoprotein water-soluble, up to $94 \%$ dissolving after digestion. 5 . The Pronase digestion products of the mucoproteins were separated from protein by equilibriumdensity-gradient centrifugation in a $\mathrm{CsCl}$ gradient. 6. These Pronase-digested mucoproteins were further fractionated on Sepharose 4B and the isolated fractions analysed by chemical and sedimentation-velocity methods. 7. Pronase digestion and solvent extraction of mucosal scrapings labelled with ${ }^{14} \mathrm{C}$ in the carbohydrate and ${ }^{3} \mathrm{H}$ in the protein showed that one type of mucoprotein was the only non-diffusible biosynthetic product of the scrapings in vitro, and that this mucoprotein was the only mucoprotein constituent of the water-soluble and water-insoluble mucus.
\end{abstract}

This paper describes the initial experiments in a systematic study of the components of gastric mucus. Because of the known complexity of gastric secretions (Glass, 1965) attempts were made to simplify the system by studying only washed mucosal scrapings. To identify the components of mucous secretions it was considered necessary first to study the metabolism of the mucosal cells and, in particular, to label radioactively the macromolecules in their secretions.

Preparations from a number of mucus-secreting tissues have been shown to be metabolically active in vitro and to incorporate radioactivity from suitable radioactive precursors into the mucoprotein of their mucous secretions. Such preparations include mucosal scrapings from sheep colon(Draper \& Kent, 1963) and human stomach (Kent \& Allen, 1968), and slices of sheep and ox submaxillary glands (Schauer et al., 1968). The experiments in the present paper describe the further development of these techniques and their application to the study of the metabolism and production of radioactive mucoproteins by gastric mucosal scrapings in vitro. Further, Pronase digestion followed by solvent extraction has been used to solubilize the mucoproteins of the insoluble mucus for comparison with the previously characterized mucoproteins of the water-soluble mucus (Snary \& Allen,
1971). A preliminary report of this work has been published (Snary \& Allen, 1969).

\section{Experimental}

\section{Materials}

Enzymes. The following enzyme preparations were supplied by Sigma (London) Chemical Co. Ltd., London S.W.6, U.K.: ficin (EC 3.4.4.12; crude freezedried powder), papain (EC 3.4.4.10; crystalline suspension in sodium acetate buffer, $\mathrm{pH} 4.5$ ) and pepsin (EC 3.4.4.1; freeze-dried powder from pig stomach). Calbiochem Ltd., London W.1, U.K., supplied Pronase B (freeze-dried material).

Radioactive isotopes. All radioactive compounds were obtained from The Radiochemical Centre, Amersham, Bucks., U.K. The specific radioactivities of the isotopes were as follows: $\mathrm{DL}-\left[\mathrm{G}-{ }^{3} \mathrm{H}\right]$ threonine, $150 \mathrm{mCi} / \mathrm{mmol}$; DL-[G- ${ }^{3} \mathrm{H}$ ]serine, $20 \mathrm{mCi} / \mathrm{mmol}$; D[U- ${ }^{14}$ C]glucose, $250 \mathrm{mCi} / \mathrm{mmol} ; \mathrm{Na}_{2}{ }^{35} \mathrm{SO}_{4}$, carrierfree. All radioisotopes used were checked for purity by chromatography. Radioactivity was measured in a Beckman LS 200 liquid-scintillation counter with scintillation fluid prepared as described by Herberg (1960). Insoluble samples were digested for about

Vol. 127 
$20 \mathrm{~min}$ with $2 \mathrm{M}-\mathrm{NaOH}(10 \mathrm{mg} / \mathrm{ml})$ at $85^{\circ} \mathrm{C}$ until solubilized. All samples were counted for radioactivity until there was a less than $5 \%$ error in the counts registered. Radioactivity on chromatograms was measured by eluting sections of chromatograms with up to $0.4 \mathrm{ml}$ of water directly into scintillation vials and adding $10 \mathrm{ml}$ of scintillation fluid.

\section{Methods}

Analytical methods. The methods used for hydrolysis and chromatography of the neutral sugars, hexosamines and amino acids were those of Allen \& Kent (1968). Ester sulphate was liberated by hydrolysis in $6 \mathrm{M}-\mathrm{HCl}$ for $18 \mathrm{~h}$ at $110^{\circ} \mathrm{C}$. The hydrolysate was evaporated to dryness under vacuum $\left[4.0 \mathrm{kN} / \mathrm{m}^{2}\right.$ $(30 \mathrm{mmHg})]$ at $40^{\circ} \mathrm{C}$, and the residue dissolved in $0.5 \mathrm{ml}$ of water and chromatographed with ethyl acetate-pyridine-acetic acid-water $(5: 5: 1: 3$, by vol.) (Fischer \& Nebel, 1955).

Protein was measured by the method of Lowry et al. (1951), with bovine serum albumin as standard. Carbohydrate-positive material eluted from columns was determined by the anthrone method of Seifter et al. (1950). Quantitative values of hexose were determined by the orcinol method of Weimer \& Moshin (1953) with galactose as a standard. Values obtained for total hexose by the orcinol determination were corrected for interference by fucose, which gave $63 \%$ by wt. of the $E_{540}$ value obtained with galactose. Fucose was measured by the method of Gibbons (1955) and hexosamines by the method of Ludoweig \& Benmaman (1967).

Preparation of tissue. Stomachs were collected in ice immediately after slaughter of the animals. The stomachs were opened from the cardio-oesophageal entrance along the lesser curvature to the pyloric sphincter. The contents of the stomach were removed and the stomach was washed thoroughly with cold water. Where obvious anatomical differences were seen between the pyloric, fundic and cardiac regions the stomach was sectioned accordingly. The mucosal surface of the sections was scraped with a scalpel and the scrapings were placed in icecold modified Krebs-Ringer medium III (Draper \& Kent, 1963). In all experiments pooled samples of scrapings from four stomachs were used.

Respiration and incorporation of radioactivity by the tissue. (a) Measurement of respiration and incorporation of radioactivity. Mucosal scrapings were incubated in manometer flasks with simultaneous measurement of respiration. To the Krebs-Ringer medium used for these incubations was added $20 \mu \mathrm{Ci}$ of $\mathrm{Na}_{2}{ }^{35} \mathrm{SO}_{4}$ or $1 \mu \mathrm{Ci}$ of $\mathrm{D}^{\mathrm{C}}\left[\mathrm{U}-{ }^{14} \mathrm{C}\right] \mathrm{glucose}$. Experiments were terminated by the addition of trichloroacetic acid (final concn. $5 \%$ ).

(b) Preparation of radioactive material. Mucosal scrapings were incubated in stoppered flasks at $37^{\circ} \mathrm{C}$ for $2 \frac{1}{2} \mathrm{~h}$. The incubation mixture contained $15 \mathrm{ml}$ of Krebs-Ringer medium and $5 \mathrm{ml}$ of scrapings, together with $10 \mu \mathrm{Ci}$ of $\mathrm{D}-\left[\mathrm{U}-{ }^{14} \mathrm{C}\right]$ glucose, $60 \mu \mathrm{Ci}$ of $\mathrm{DL}-$ [G- $\left.{ }^{3} \mathrm{H}\right]$ serine or $60 \mu \mathrm{Ci}$ of $\mathrm{DL}-\left[\mathrm{G}-{ }^{3} \mathrm{H}\right]$ threonine. In many experiments [U- ${ }^{14} \mathrm{C}$ ]glucose was added to the incubation medium together with one of the tritiated amino acids. The incubations were terminated by the addition of 3 vol. of ethanol.

The products of incubation were dialysed at $4^{\circ} \mathrm{C}$ against 2 litres of water for 4 days, with three changes of water a day. No radioactivity was incorporated by the control incubation mixtures containing tissue previously killed by treatment with trichloroacetic acid (final concn. $5 \%$ ). Samples containing $\mathrm{Na}_{2}{ }^{35} \mathrm{SO}_{4}$ were first dialysed against $2 \times 2$ litres of $5 \%(\mathrm{w} / \mathrm{v})$ nonradioactive $\mathrm{Na}_{2} \mathrm{SO}_{4}$ for $24 \mathrm{~h}$ at $4^{\circ} \mathrm{C}$ before dialysis against water.

Dry weights of tissues and mucins were measured from freeze-dried materials.

Solvent extractions. After dialysis of the mucosal scrapings, the non-diffusible material was centrifuged at $5000 \mathrm{~g}$ for $20 \mathrm{~min}$ to separate a water-soluble fraction from a water-insoluble residue. In some experiments the water-insoluble residue was further extracted with $100 \mathrm{ml}$ of one or more of the following solvents: $8 \mathrm{M}$-urea, $0.2 \mathrm{M}$-2-mercaptoethanol, $2 \mathrm{M}$ $\mathrm{NaCl}, 2 \%(\mathrm{w} / \mathrm{v})$ sodium deoxycholate or $0.5 \mathrm{M}$-formic acid. Each solvent extraction was carried out for 4 days with gentle shaking at $4^{\circ} \mathrm{C}$. The soluble fractions were removed after centrifuging the extract at $5000 \mathrm{~g}$ for $20 \mathrm{~min}$.

Assay of blood-group activity. Blood-group A activity was assayed by the method of Kabat \& Bezer (1945). The dilution of antiserum that just gave complete agglutination of a $4 \%(\mathrm{v} / \mathrm{v})$ suspension of erythrocytes was used. The blood-group activity of the material was expressed as the amount of material $(\mu \mathrm{g} / 0.1 \mathrm{ml})$ that just inhibited complete agglutination of the erythrocytes by the antiserum.

Enzyme digestions. Pepsin digestions were carried out by the method of Kabat (1956). Mucosal scrapings $(5 \mathrm{ml}$; about $500 \mathrm{mg}$ freeze-dried wt.) were incubated with $100 \mathrm{mg}$ of pepsin in $15 \mathrm{ml}$ of $0.5 \mathrm{M}$ sodium citrate, $\mathrm{pH}$ 2.3. Papain digestions were carried out by the method of Kimmel \& Smith (1954). The digestion medium contained $3.5 \mathrm{ml}$ of water, $1 \mathrm{ml}$ of $0.2 \mathrm{M}$-sodium citrate, $\mathrm{pH} 5.0,0.5 \mathrm{ml}$ of papain $(3.0 \mathrm{mg} /$ $\mathrm{ml}$ ) and $30 \mathrm{mg}$ of freeze-dried mucosal scrapings. The papain was prepared as described by Kimmel \& Smith (1954). Pronase digestions were carried out by the method of Ambler (1963). The incubation medium contained $30 \mathrm{mg}$ of freeze-dried scrapings and $5 \mathrm{mg}$ of Pronase in $5.0 \mathrm{ml}$ of $0.2 \mathrm{M}$-ammonium acetate, pH6.5. Ficin digestions were by the method of Pusztai \& Morgan (1961). The incubation mixture contained $30 \mathrm{mg}$ of scrapings, $5 \mathrm{mg}$ of ficin and $5 \mathrm{ml}$ of $0.2 \mathrm{M}$-sodium phosphate-0.1 $\mathrm{M}$-sodium citrate$0.01 \mathrm{M}-\mathrm{KCN}$ at $\mathrm{pH} 4$. All incubations were continued 
for 3 days, with further amounts of enzyme added after 24 and $48 \mathrm{~h}$. Two or three crystals of thymol were added to prevent bacterial growth. Incubations were performed at $37^{\circ}$ and $60^{\circ} \mathrm{C}$ and, in some experiments, scrapings were incubated at $100^{\circ} \mathrm{C}$ for $15 \mathrm{~min}$ before enzymic digestion.

The products from Pronase digestion were fractionated by using $\mathrm{CsCl}$ equilibrium density-gradient centrifugation (Creeth \& Denborough, 1970). The freeze-dried digestion products were dissolved in $\mathrm{CsCl}$ soln., density $1.42 \mathrm{~g} / \mathrm{ml}$, and centrifuged at $43000 \mathrm{rev}$./min for $48 \mathrm{~h}$ in an MSE Superspeed 50 preparative ultracentrifuge, in $10 \mathrm{ml}$ polycarbonate tubes. Complete separation of protein (at the top of the tube, final $\mathrm{CsCl}$ density $1.38 \mathrm{~g} / \mathrm{ml}$ ) from the mucoproteins (at the base of the tube, final $\mathrm{CsCl}$ density $1.56 \mathrm{~g} / \mathrm{ml}$ ) was obtained after centrifuging for $48 \mathrm{~h}$ (D. Snary \& A. Allen, unpublished work). The mucoprotein was further fractionated by using Sephadex G-100 $(25 \mathrm{~cm} \times 1 \mathrm{~cm})$ and Sepharose 4B $(25 \mathrm{~cm} \times 2 \mathrm{~cm})$ columns eluted by water. Sedimentation-velocity studies were performed by using a Beckman model $\mathrm{E}$ analytical ultracentrifuge with the mucoprotein dissolved in a buffer of $0.18 \mathrm{M}-\mathrm{KCl}-0.02 \mathrm{M}$-potassium acetate $-0.02 \% \mathrm{NaN}_{3}, \mathrm{pH} 5.5$, as described by Snary \& Allen (1971).

\section{Results}

\section{Metabolism of pig gastric mucosal tissue in vitro}

Surface scrapings from the different anatomical regions of the pig stomach were incubated manometrically in the presence of $1 \mu \mathrm{Ci}$ of $\mathrm{D}-\left[\mathrm{U}-{ }^{14} \mathrm{C}\right]-$ glucose for $2 \frac{1}{2} \mathrm{~h}$ at $37^{\circ} \mathrm{C}$. The metabolic activity of the scrapings was measured by three parameters: oxygen absorption, radioactivity from the $\left[\mathrm{U}-{ }^{14} \mathrm{C}\right]$ glucose liberated as ${ }^{14} \mathrm{CO}_{2}$ and radioactivity incorporated into the non-diffusible material from $\left[\mathrm{U}^{14} \mathrm{C}\right]$ glucose (Table 1). In all preparations the metabolic activity, as measured by oxygen uptake, ceased within $2 \frac{1}{2} h$ of the start of the incubation (Fig. 1). Mucosal scrapings from the cardiac region of pig stomach incorporated the most radioactivity from $\left[\mathrm{U}-{ }^{14} \mathrm{C}\right]-$ glucose into the non-diffusible material and this source of tissue was therefore used for all further experiments.

The metabolic activity of the scrapings was not affected by the addition of penicillin $G$ (final concn. 500 units $/ \mathrm{ml}$ ) and of streptomycin (final concn. $0.1 \mathrm{mg} / \mathrm{ml}$ ). The specific radioactivity of the non-diffusible material from incubations with $\left[\mathrm{U}-{ }^{14} \mathrm{C}\right]-$ glucose was 440 d.p.m./mg in the presence of antibiotics and 440 d.p.m./mg in the absence of antibiotics (average of two experiments). Similarly, the oxygen uptake by the mucosal scrapings incubated in the presence and absence of antibiotic was 1.4 and $1.1 \mu \mathrm{l}$ of oxygen $/ \mathrm{mg}$ dry wt. of tissue (average of two experiments) respectively.

The optimum $\mathrm{pH}$ for metabolic activity of mucosal scrapings was studied by incubating scrapings manometrically in modified Krebs-Ringer medium containing $\left[\mathrm{U}^{14} \mathrm{C}\right] \mathrm{glucose}$ and buffered with sodium phosphate or 3,3-dimethylglutaric acid at different $\mathrm{pH}$ values in the range $\mathrm{pH} 3.2-8.9$. The $\mathrm{pH}$ optimum for oxygen absorption, ${ }^{14} \mathrm{CO}_{2}$ release and incorporation of radioactivity into the non-diffusible material was found in all three cases to be pH7.4 (Table 2). To compare these results with the $\mathrm{pH}$ of the stomach contents of pigs, ten stomachs were collected from two separate batches of slaughtered animals and the $\mathrm{pH}$ of the stomach contents was measured. The $\mathrm{pH}$

Table 1. Metabolism of pig gastric mucosal scrapings incubated in vitro with $\mathrm{D}-\left[\mathrm{U}-{ }^{14} \mathrm{C}\right] \mathrm{glucose}$

Incubations were performed in manometer flasks containing in the main compartment $3 \mathrm{ml}$ of modified KrebsRinger medium III, $1 \mathrm{ml}$ of tissue (approx. $60 \mathrm{mg}$ dry wt.) and $1 \mu \mathrm{Ci}$ of $\mathrm{D}-\left[\mathrm{U}-{ }^{14} \mathrm{C}\right] \mathrm{glucose} ; 0.2 \mathrm{ml}$ of $2 \mathrm{M}-\mathrm{NaOH}$ was included in the centre well of the flasks to trap released $\mathrm{CO}_{2}$. Incubations were for $2 \frac{1}{2} \mathrm{~h}$ at $37^{\circ} \mathrm{C}$, and were terminated by the addition of $0.5 \mathrm{ml}$ of $30 \%(\mathrm{w} / \mathrm{v})$ trichloroacetic acid from the side arms of the flasks. The results are average values from at least three experiments; numbers in parentheses represent the range of values obtained.

\begin{tabular}{|c|}
\hline $\begin{array}{l}\text { Anatomical } \\
\text { region } \\
\text { of } \\
\text { stomach }\end{array}$ \\
\hline $\begin{array}{l}\text { Cardiac } \\
\text { Fundic } \\
\text { Pyloric }\end{array}$ \\
\hline
\end{tabular}

Vol. 127
Radioactivity incorporated into non-diffusible material

$\begin{array}{cc}\begin{array}{c}\text { Sp. radioactivity } \\ \text { (d.p.m./mg dry wt. } \\ \text { of tissue) }\end{array} & \begin{array}{c}\text { \% of added } \\ \text { radioactivity }\end{array} \\ 5500( \pm 2500) & 18.7 \\ 3070( \pm 2000) & 7.0 \\ 1600( \pm 890) & 4.8\end{array}$
Oxygen absorbed
( $\mu 1 / \mathrm{mg}$ dry wt. of tissue)
$4.0( \pm 1.7)$
$2.9( \pm 1.0)$
$1.3( \pm 0.5)$


values were found to vary between 2.6 and 6.9. In all cases the measured $\mathrm{pH}$ of the stomach contents was below pH7.4, the optimum $\mathrm{pH}$ for the metabolic activity of the scrapings in vitro.

The distribution of radioactivity incorporated from [U- ${ }^{14} \mathrm{C}$ ]glucose into the sugars of the non-diffusible material was examined by acid hydrolysis and paper chromatography. After hydrolysis for $3 \mathrm{~h}$ at $105^{\circ} \mathrm{C}$ in $0.25 \mathrm{M}-\mathrm{H}_{2} \mathrm{SO}_{4}$, chromatography showed the following sugars to be present: glucose, galactose, mannose, fucose, glucosamine and galactosamine, and a trace of ribose. Hydrolysis for $16 \mathrm{~h}$ at $105^{\circ} \mathrm{C}$ in $2 \mathrm{M}-\mathrm{HCl}$, primarily for the release of hexosamines, followed by

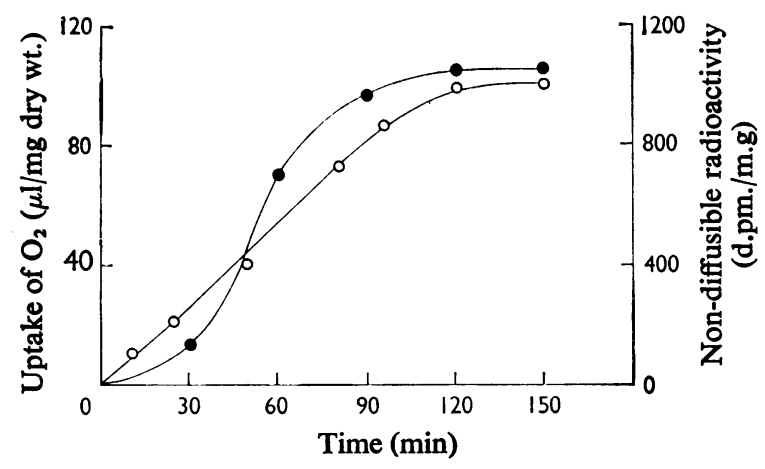

Fig. 1. Oxygen uptake by and incorporation of radioactivity into the non-diffusible fraction by pig stomach cardiac mucosal scrapings

Incubations were performed as described in Table 1. $\circ$, Uptake of oxygen ( $\mu \mathrm{l} / \mathrm{mg}$ dry wt. of tissue); $\bullet$, radioactivity in the non-diffusible fraction. chromatography, indicated that the material contained glucosamine and galactosamine as well as a wide spectrum of amino acids. The radioactivity in the non-diffusible material was distributed amongst the component sugars as follows: galactose $57 \%$, fucose $8 \%$, glucosamine and galactosamine $20 \%$. No radioactivity was found in any of the other sugars or in the amino acids.

The metabolism of different tissue sections from the stomach wall, namely surface mucosal scrapings, pieces of mucosal layer removed from the underlying tissue and slices of whole stomach wall, was studied (Table 3). The surface mucosal scrapings had the highest oxygen absorption, ${ }^{14} \mathrm{CO}_{2}$ release and incorporation of radioactivity from $\left[\mathrm{U}^{14}{ }^{14} \mathrm{C}\right]$ glucose into the non-diffusible material of the three tissue sections tried. In contrast the specific radioactivity of the nondiffusible material labelled from $\mathrm{Na}_{2}{ }^{35} \mathrm{SO}_{4}$ was the highest for pieces of mucosal sheet. Acid hydrolysis and chromatography showed that all the radioactivity incorporated from $\mathrm{Na}_{2}{ }^{35} \mathrm{SO}_{4}$ into the mucosal sheet was present as ester sulphate; a single radioactive spot co-chromatographed with standard radioactive sulphate $\left(R_{\text {methionine }} 0.8\right)$, and no radioactivity was found in cystine and cysteine $\left(R_{\text {methionine }} 0.1\right)$ or methionine.

The incorporation of radioactivity from $\left[\mathrm{G}-{ }^{3} \mathrm{H}\right]-$ threonine and $\left[\mathrm{G}-{ }^{3} \mathrm{H}\right]$ serine into the non-diffusible material is shown in Table 4. Acid hydrolysis and chromatography in both ethyl acetate-pyridineacetic acid-water $(5: 5: 3: 1$, by vol.) and ethanol$\mathrm{NH}_{3}$ soln. (sp.gr. 0.88)-water $(18: 1: 1$, by vol), showed that $\left[\mathrm{G}-{ }^{3} \mathrm{H}\right]$ serine was incorporated solely as serine. By using the same solvents $\left[\mathrm{G}-{ }^{3} \mathrm{H}\right]$ threonine was shown to be incorporated as glycine and threonine containing 50 and $47 \%$ of the total radioactivity respectively.

Table 2. Metabolism of pig stomach cardiac mucosal scrapings incubated in vitro in media of different pH values with $\mathrm{D}-\left[U^{-14} C\right]$ glucose

Incubations were performed as described in Table 1. The pH7.4 medium was modified Krebs-Ringer medium III, other $\mathrm{pH}$ values were achieved by replacing the sodium phosphate buffer in modified Krebs-Ringer medium III with $0.154 \mathrm{M}-3,3-$ dimethylglutaric acid adjusted to the required $\mathrm{pH}$ with $0.154 \mathrm{M}-\mathrm{NaOH}$ (final concn. of 3,3-dimethylglutaric acid, $4 \mathrm{mmol} / 1$ ). The $\mathrm{pH}$ of the whole medium was adjusted to the required value where necessary with $0.2 \mathrm{M}-\mathrm{HCl}$ or $0.2 \mathrm{M}-\mathrm{NaOH}$. The results are average values from four experiments; numbers in parentheses represent the range of values obtained.

$\begin{array}{cccc}\begin{array}{c}\text { pH of } \\ \text { medium }\end{array} & \begin{array}{c}\text { Sp. radioactivity of } \\ \text { non-diffusible material } \\ \text { (d.p.m./mg dry wt. of tissue) }\end{array} & \begin{array}{c}\text { Radioactivity released as }{ }^{14} \mathrm{CO}_{2} \\ \text { (d.p.m./mg dry wt. of tissue) }\end{array} & \begin{array}{c}\text { Oxygen absorbed } \\ (\mu 1 / \text { mg dry wt. of tissue) }\end{array} \\ 3.2 & 31( \pm 4) & 35( \pm 13) & 0.5( \pm 0.1) \\ 5.0 & 1730( \pm 370) & 1830( \pm 150) & 1.8( \pm 0.3) \\ 6.9 & 4480( \pm 180) & 2750( \pm 130) & 3.5( \pm 0.5) \\ 7.4 & 5340( \pm 600) & 3380( \pm 100) & 4.4( \pm 0.2) \\ 8.9 & 1360( \pm 700) & 1410( \pm 400) & 2.7( \pm 1.3)\end{array}$


Table 3. Metabolism of different tissue sections from the wall of the cardiac region of pig stomach incubated in vitro with $\mathrm{D}-\left[\mathrm{U}-{ }^{14} \mathrm{C}\right]$ glucose or $\mathrm{Na}_{2}{ }^{35} \mathrm{SO}_{4}$

Incubations were performed as described in Table 1 , with either $1 \mu \mathrm{Ci}$ of $\mathrm{D}-\left[\mathrm{U}-{ }^{14} \mathrm{C}\right]$ glucose or $10 \mu \mathrm{Ci}$ of $\mathrm{Na}_{2}{ }^{35} \mathrm{SO}_{4}$ added to the incubation medium. Incubations with added $\mathrm{Na}_{2}{ }^{35} \mathrm{SO}_{4}$ had $\mathrm{MgSO}_{4}$ omitted from the modified Krebs-Ringer medium III and $\mathrm{MgCl}_{2}$ added (final concn. $2 \mathrm{mmol} / \mathrm{l}$ ). After incubation with $\mathrm{Na}_{2}{ }^{35} \mathrm{SO}_{4}$ samples were dialysed at $4^{\circ} \mathrm{C}$ against $2 \times 2$ litres of $5 \%$ (w/v) $\mathrm{Na}_{2} \mathrm{SO}_{4}$ for $24 \mathrm{~h}$ before dialysis against water. The results are average values from three experiments; numbers in parentheses represent the range of values obtained.

\begin{tabular}{|c|c|c|c|c|c|}
\hline Tissue section & $\begin{array}{l}\text { Dry wt. } \\
\text { of tissue } \\
\text { (mg) }\end{array}$ & $\begin{array}{c}\text { Sp. radioactivity of } \\
\text { non-diffusible } \\
\text { material labelled } \\
\text { from } \mathrm{Na}_{2}{ }^{35} \mathrm{SO}_{4} \\
\text { (d.p.m./mg dry wt. } \\
\text { of tissue) }\end{array}$ & $\begin{array}{c}\text { Sp. radioactivity of } \\
\text { non-diffusible } \\
\text { material labelled } \\
\text { from } D-\left[U-{ }^{14} \text { C]glucose }\right. \\
\text { (d.p.m./mg dry wt. } \\
\text { of tissue) }\end{array}$ & $\begin{array}{c}\text { Radioactivity } \\
\text { released as }{ }^{14} \mathrm{CO}_{2} \\
\text { (d.p.m./mg dry wt. } \\
\text { of tissue) }\end{array}$ & $\begin{array}{c}\text { Oxygen } \\
\text { absorbed } \\
(\mu 1 / \mathrm{mg} \\
\text { dry wt. } \\
\text { of tissue })\end{array}$ \\
\hline $\begin{array}{l}\text { Surface mucosal } \\
\text { scrapings }\end{array}$ & 74 & $60( \pm 60)$ & $12700( \pm 1000)$ & $1440( \pm 700)$ & $3.1( \pm 0.9)$ \\
\hline $\begin{array}{l}\text { Pieces of mucosal } \\
\text { sheet }\end{array}$ & 150 & $1270( \pm 500)$ & $1200( \pm 220)$ & $910( \pm 400)$ & $0.8( \pm 0.2)$ \\
\hline $\begin{array}{l}\text { Slices of stomach } \\
\text { wall }\end{array}$ & 332 & $310( \pm 100)$ & $520( \pm 168)$ & $740( \pm 250)$ & $0.4( \pm 0.1)$ \\
\hline
\end{tabular}

Table 4. Water-soluble non-diffusible radioactivity present in pig stomach cardiac mucosal scrapings previously incubated with either $\mathrm{D}-\left[\mathrm{U}-{ }^{14} \mathrm{C}\right]$ glucose, DL- $\left[\mathrm{G}_{-}{ }^{3} \mathrm{H}\right]$ threonine or DL- $\left[\mathrm{G}-{ }^{3} \mathrm{H}\right]$ serine

The methods are described in the Experimental section. The incubation mixture (total volume $20 \mathrm{ml}$ ) contained $10 \mu \mathrm{Ci}$ of $\mathrm{D}-\left[\mathrm{U}-{ }^{14} \mathrm{C}\right]$ glucose, $60 \mu \mathrm{Ci}$ of DL-[G- $\left.{ }^{3} \mathrm{H}\right]$ serine or $60 \mu \mathrm{Ci}$ of DL-[G- $\left.{ }^{3} \mathrm{H}\right]$ threonine. The results are average values from six experiments; numbers in parentheses represent the range of results obtained.

$\begin{array}{lccc} & \begin{array}{c}\text { Sp. radioactivity of } \\ \text { non-diffusible material } \\ \text { (d.p.m./mg dry wt. of tissue) }\end{array} & \begin{array}{c}10^{-6} \times \text { Total non- } \\ \text { diffusible radioactivity } \\ \text { (d.p.m.) }\end{array} & \begin{array}{c}\text { Water-soluble non- } \\ \text { diffusible radioactivity } \\ (\% \text { of total) }\end{array} \\ \text { D-[U- }{ }^{14} \text { C]Glucose } & 5500 & 1.42 & 21.8( \pm 12.4) \\ \text { DL-[G- }{ }^{3} \text { H]Threonine } & 22800 & 4.58 & 23.5( \pm 1.9) \\ \text { DL-[G- }{ }^{3} \text { H]Serine } & 10280 & 3.32 & 21.8( \pm 6.6)\end{array}$

\section{Fractionation of the non-diffusible material}

The distribution of the radioactivity between the water-soluble and water-insoluble fractions of the non-diffusible radioactivity incorporated into the mucosal scrapings from $\left[\mathrm{U}-{ }^{14} \mathrm{C}\right] \mathrm{glucose},\left[\mathrm{G}-{ }^{3} \mathrm{H}\right]-$ threonine and $\left[\mathrm{G}-{ }^{3} \mathrm{H}\right]$ serine is shown in Table 4. An average of about $22 \%$ of the radioactivity in the nondiffusible material was found to be water-soluble for all three radioactive labels used. The water-soluble fraction constituted between 4.2 and $15.1 \%$ (average $8.2 \%$, four experiments) by weight of the freezedried non-diffusible material. With material labelled from $\left[\mathrm{U}-{ }^{14} \mathrm{C}\right] \mathrm{glucose}$ the specific radioactivity of the water-soluble fraction was $10400( \pm 3000)$ d.p.m./mg dry wt., compared with 3900 ( \pm 500 ) d.p.m./mg dry wt. for the total non-diffusible fraction. Only a further $0.2-3.0 \%$ (average $1.2 \%$, from 12 experiments) of the total radioactivity from $\left[\mathrm{U}-{ }^{14} \mathrm{C}\right]$ glucose in the non- diffusible material was solubilized by shaking the water-insoluble residue with another $100 \mathrm{ml}$ of water for 4 days at $4^{\circ} \mathrm{C}$. The possibility that 3 vol. of ethanol added at the end of the incubation in vitro may affect the amount of radioactivity that was water-soluble was studied by omitting the addition of ethanol to some incubations. No significant difference was found between the percentage of water-soluble radioactivity in the non-diffusible material with ethanol $(9.8-16.7 \%$; average $12.5 \%$, four experiments) or without ethanol $(7.0-17.8 \%$; average $12.0 \%$, four experiments).

The water-insoluble radioactivity of the nondiffusible material labelled from [U-14 $\mathrm{C}]$ glucose and [G- $\left.{ }^{3} \mathrm{H}\right]$ threonine was further solubilized by treatment with $0.2 \mathrm{M}$-mercaptoethanol, $8 \mathrm{M}$-urea or $0.5 \mathrm{M}$ formic acid (Table 5). $2 \mathrm{M}$-Sodium chloride solubilized only a further $12 \%$ of the water-insoluble radio- 
Table 5. Solubility in different solvents of radioactive non-diffusible material from pig stomach cardiac mucosal scrapings previously incubated with $\mathrm{D}-\left[U-{ }^{14} \mathrm{C}\right]$ glucose and $\mathrm{DL}-\left[\mathrm{G}-{ }^{3} \mathrm{H}\right]$ threonine

The methods are described in the Experimental section. The results are average values from three experiments; numbers in parentheses represent the range of values obtained.

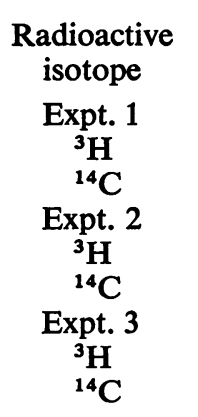

$\begin{array}{cc}\text { First extraction } & \text { Second extraction } \\ \text { Water } & 0.2 \mathrm{M} \text {-Mercaptoethanol } \\ 27.4( \pm 7.4) & 7.1( \pm 3.2) \\ 26.3( \pm 4.1) & 7.9( \pm 1.9) \\ \text { Water } & 8 \mathrm{M}-\text { Urea } \\ 20.5( \pm 5.3) & 33.4( \pm 5.1) \\ 20.9( \pm 6.1) & 34.0( \pm 9.2) \\ \text { Water } & 0.5 \mathrm{M}-\text { Formic acid } \\ 11.1( \pm 0.9) & 5.1( \pm 2.1) \\ 11.1( \pm 2.1) & 4.8( \pm 0.9)\end{array}$

$\%$ of total radioactivity solubilized by solvent

Table 6. Solubility after proteolytic digestion of the non-diffusible material radioactively labelled from $\mathrm{D}-\left[U-{ }^{14} \mathrm{C}\right] \mathrm{glucose}$

The experimental conditions are described in the Experimental section. The results are average values from three experiments; numbers in parentheses represent the range of values obtained.

\begin{tabular}{|c|c|c|c|c|}
\hline \multirow[b]{2}{*}{ Enzyme } & \multirow[b]{2}{*}{$\begin{array}{c}\text { Incubation } \\
\text { temperature } \\
\left({ }^{\circ} \mathrm{C}\right)\end{array}$} & \multirow{2}{*}{$\begin{array}{l}\text { Total non-diffusible } \\
\text { radioactivity present } \\
\text { (d.p.m.) }\end{array}$} & \multicolumn{2}{|c|}{ Soluble radioactivity } \\
\hline & & & d.p.m. & $\begin{array}{l}\% \text { of total } \\
\text { radioactivity }\end{array}$ \\
\hline \multirow[t]{2}{*}{ Pronase } & $\begin{array}{l}37 \\
37 *\end{array}$ & $\begin{array}{r}105000 \\
99000\end{array}$ & $\begin{array}{l}98000 \\
85000\end{array}$ & $\begin{array}{l}93.5( \pm 1.0) \\
86.0( \pm 1.5)\end{array}$ \\
\hline & 60 & 108000 & 101000 & $93.7( \pm 1.5)$ \\
\hline \multirow[t]{3}{*}{ Papain } & 37 & 89000 & 78500 & $88.2( \pm 0.8)$ \\
\hline & $37^{*}$ & 103000 & 78000 & $76.2( \pm 4.1)$ \\
\hline & 60 & 86000 & 73000 & $85.0( \pm 2.1)$ \\
\hline \multirow[t]{3}{*}{ Ficin } & 37 & 80000 & 65000 & $81.2( \pm 1.0)$ \\
\hline & $37^{*}$ & 72000 & 52000 & $65.0( \pm 3.1)$ \\
\hline & 60 & 81000 & 64000 & $79.1( \pm 3.0)$ \\
\hline Pepsin & 37 & 887000 & 346000 & $39.0( \pm 2.0)$ \\
\hline
\end{tabular}

activity. A second extraction with $100 \mathrm{ml}$ of a solvent solubilized only a further $0.2-0.8 \%$ of the radioactivity present in the non-diffusible material. Between 94 and $98 \%$ of the radioactivity solubilized by these solvents was found to be soluble after dialysis against water. Sodium deoxycholate $(0.2 \%, \mathrm{w} / \mathrm{v})$ solubilized $37.7 \%$ of the water-insoluble radioactivity in the non-diffusible fraction; however, after dialysis against water, only $2.4 \%$ of the radioactivity was found to be soluble in water. Table 5 shows that the maximum amount of radioactivity solubilized by any of the combinations of solvents tried was still only $78 \%$ of the total non-diffusible radioactivity in the mucosal scrapings. Table 5 also shows that the same percentage of ${ }^{3} \mathrm{H}$-labelled protein and ${ }^{14} \mathrm{C}$ labelled carbohydrate were solubilized by treatment of the non-diffusible material with any one of the solvents used.

\section{Enzymic digestion of the non-diffusible material}

In an effort to solubilize the whole of the radioactivity incorporated from $\left[\mathrm{U}-{ }^{14} \mathrm{C}\right]$ glucose into the non-diffusible fraction, digestion with proteolytic enzymes was tried (Table 6). Papain, ficin and Pronase solubilized a similar percentage of radioactivity under all conditions used. Pepsin was less 
effective, only $39 \%$ of the total radioactivity in the sample being solubilized after digestion.

Pronase-digestion products $\left(37^{\circ} \mathrm{C}\right.$ incubation) were chosen for further study and a summary of the procedures used is shown in Scheme 1. The identities of the Pronase-digestion products from the watersoluble fraction (fraction PS) and the water-insoluble fraction (fraction PI) were investigated as follows. Gel filtration on Sephadex G-100 of both fractions PS and PI gave identical elution profiles, with all the hexose-positive material (anthrone method) in the excluded volume. Further, the freeze-dried excluded peaks from gel filtration on Sephadex G-100 of fractions PS and PI had very similar blood-group A activities: $0.5 \mu \mathrm{g} / 0.1 \mathrm{ml}$ and $0.6 \mu \mathrm{g} / 0.1 \mathrm{ml}$ respectively.

The Pronase-digestion products from the watersoluble (fraction PS) and the water-insoluble (fraction PI) fractions were further compared by fractionation with $\mathrm{CsCl}$ equilibrium density-gradient centrifugation. The fractions from the bottom third of the tube, which contained after centrifugation all the carbohydrate-containing material, were then dialysed against water (six changes of water for $48 \mathrm{~h}$ ) at $4^{\circ} \mathrm{C}$ and freeze-dried. These fractions obtained from the water-soluble fraction (PS) and the water-insoluble fraction (PI) were examined by sedimentationvelocity analysis in $0.2 \mathrm{M}-\mathrm{KCl}$ buffer, $\mathrm{pH} 5.5$, at concentrations of 5 and $2.5 \mathrm{mg} / \mathrm{ml}$. Two boundaries were found to be present in each fraction. The measured $s_{25, w}$ values for each of the two components in the fractionated material from the water-soluble fraction (PS) and the material from the water-insoluble fraction (PI) respectively were closely similar (Table 7).

The freeze-dried carbohydrate-containing fractions isolated by density-gradient centrifugation from the

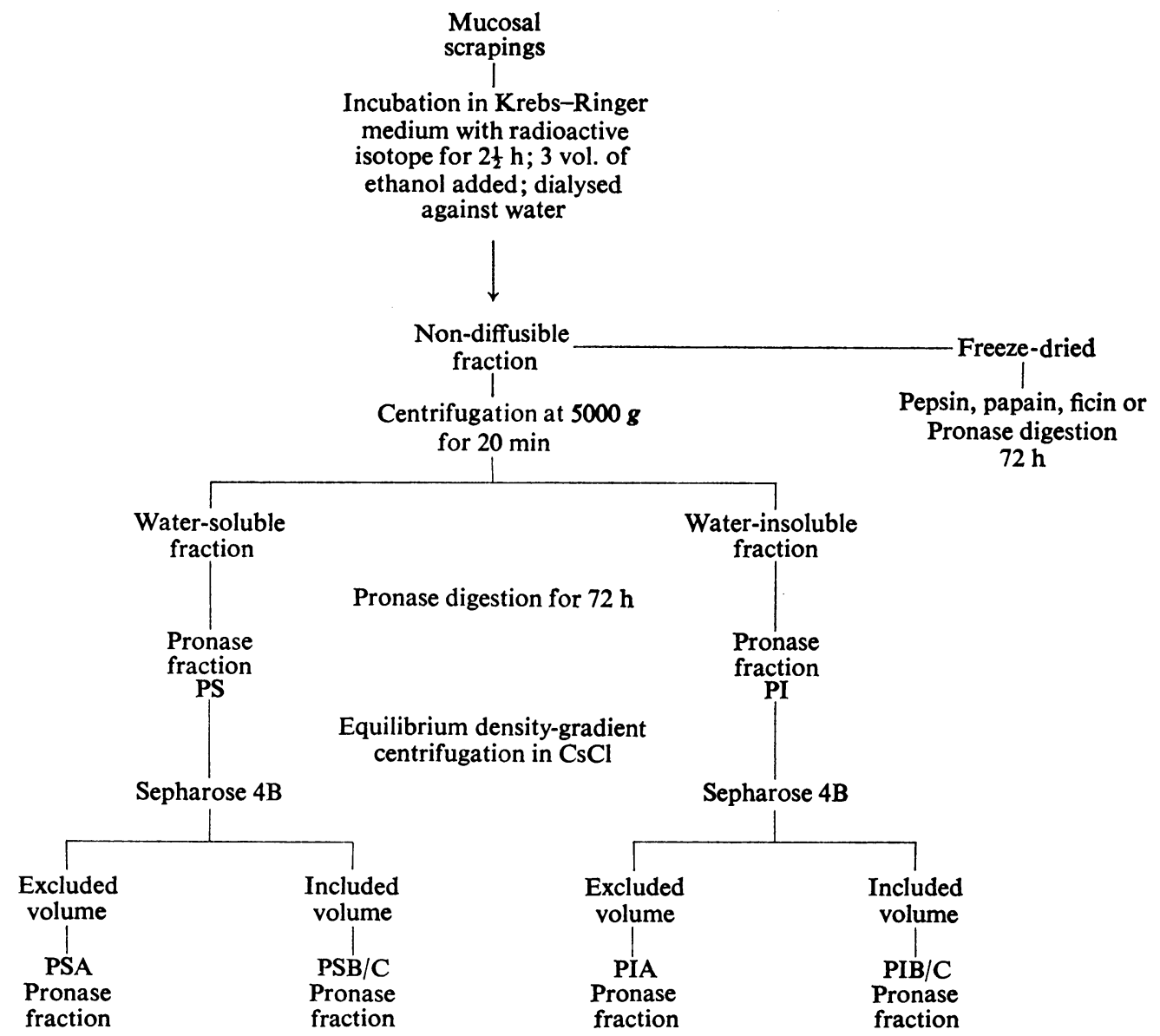

Scheme 1. Procedures used during enzymic digestion studies on pig stomach cardiac mucosal scrapings 
Table 7. Sedimentation-velocity coefficients for the fractionated Pronase-digestion products of the water-soluble and water-insoluble mucus

The methods are described in the Experimental section.

\begin{tabular}{clcccc} 
& & \multicolumn{2}{c}{$s_{25, \mathrm{w}}(\mathrm{S})$} \\
\cline { 5 - 5 } & Fraction & $\begin{array}{c}\text { Concn. of } \\
\text { sample }\end{array}$ & $\ldots$ & $5 \mathrm{mg} / \mathrm{ml}$ & $2.5 \mathrm{mg} / \mathrm{ml}$ \\
Water-soluble & PSA & & 14.1 & 21.4 \\
mucus & PSB/C & & 4.72 & 5.49 \\
Water-insoluble & PIA & & 14.0 & 20.9 \\
mucus & PSB/C & & & 4.66 & 5.44
\end{tabular}

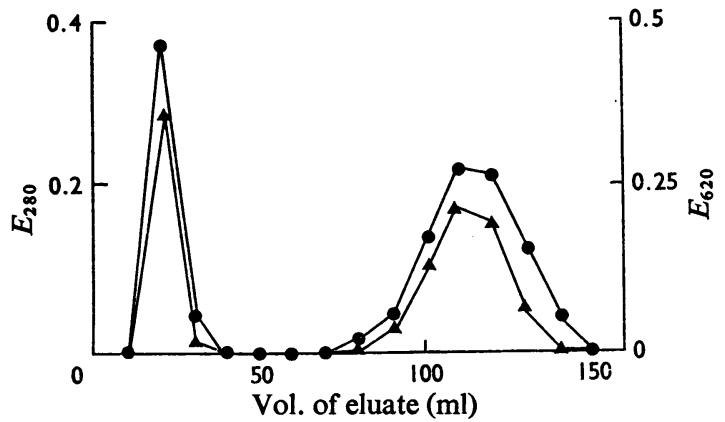

Fig. 2. Fractionation on Sepharose $4 B$ of the carbohydrate-containing fraction from the Pronase digest of the water-insoluble mucus (fraction PI)

$\bullet, E_{280} ; \Delta$, anthrone-positive material $\left(E_{620}\right)$. A sample ( $2 \mathrm{ml}$; approx. $5 \mathrm{mg}$ dry wt. $/ \mathrm{ml}$ ) was loaded on a Sepharose 4B column $(25 \mathrm{~cm} \times 2 \mathrm{~cm})$, eluted with water by downward flow and $6 \mathrm{ml}$ fractions were collected. An identical result was obtained for the Pronase digest of the water-soluble mucus.

Pronase digests of the water-soluble fraction (PS) and water-insoluble fraction (PI) were dissolved in water $(5 \mathrm{mg} / \mathrm{ml})$ and further fractionated by gel filtration on Sepharose 4B. Similar elution profiles as measured by $E_{280}$ and total hexose were given by both the water-soluble and water-insoluble fractions (Fig. 2). In both cases $45 \%$ by wt. of the mucoprotein was excluded on Sepharose 4B, the remaining $55 \%$ being in the included volume. The water-soluble fraction (PS) was separated into two fractions on Sepharose 4B, fraction PSA in the excluded volume and fraction $\mathrm{PSB} / \mathrm{C}$ in the included volume; similarly the water-insoluble fraction (PI) was separated into fractions PIA and PIB/C (Scheme 1 and Fig. 2). The overall chemical compositions of the four fractions PSA, PSB/C, PIA and PIB/C were found to be closely similar (Table 8).

\section{Discussion}

The mucosal scrapings survived in Krebs-Ringer medium for up to $2 \mathrm{~h}$, as shown by the oxygen absorption and the incorporation of radioactivity (Fig. 1). The radioactivity incorporated into the combined water-soluble and water-insoluble mucus by the mucosal scrapings from the cardiac region of pig stomach, 3000-8000d.p.m./mg dry wt., was comparable with that found for sheep colonic mucosal scrapings and human gastric scrapings (Allen, 1966; Kent \& Allen, 1968). The pH optimum of the metabolic activity was $\mathrm{pH} 7.4$, i.e. the $\mathrm{pH}$ of the Krebs-Ringer medium (Table 2). In contrast the $\mathrm{pH}$ of pig stomach contents varied between 2.6 and 6.9. Further, studies by Marcussen (1970) using electrodes in vivo have shown that a $\mathrm{pH}$ gradient exists across the stomach contents, values as high as pH7.0 being recorded at the centre of the contents and values as low as $\mathrm{pH} 1.0$ being recorded near the mucosal surface. At pH3.2 the metabolic activity of the mucosal scrapings was only $4 \%$ of the value at pH 7.4, and even at pH5.0 the metabolic activity was only $47 \%$ of the activity at $\mathrm{pH} 7.4$. This supports the idea of a protective mechanism, presumably involving the mucous layer (Florey, 1962), between the stomach contents and the mucosal cells.

The percentage of radioactivity incorporated into the water-soluble and water-insoluble mucus from $\left[\mathrm{U}-{ }^{14} \mathrm{C}\right] \mathrm{glucose}$ into different sugars was as follows: galactose, $57 \%$; glucosamine and galactosamine, $20 \%$; fucose, $8 \%$. The remaining $15 \%$ of the radioactivity unaccounted for could be explained by losses during the hydrolysis procedures; also, the radioactivity, if any, in the sialic acid residues was not measured. These sugars are the constituents of the water-soluble mucoproteins in pig gastric mucus (Snary \& Allen, 1971). Traces of mannose were present in the mucosal scrapings. However, the mannose was not radioactively labelled and it is not a constituent of the purified mucus (Snary \& Allen, 1971). It is quite possible that the mannose comes from material made elsewhere than in the cardiac 
Table 8. Chemical analysis of the fractionated Pronase-digestion products of the water-soluble and water-insoluble mucus

The methods are described in the Experimental section. Each value is an average of at least two determinations.

$\begin{array}{lccccc}\text { Fraction } & \overbrace{\begin{array}{c}\text { PSA } \\ (\%, \text { by wt. })\end{array}}^{\text {Water-soluble mucus }} & \begin{array}{c}\text { PSB/C } \\ (\%, \text { by wt. })\end{array} & \overbrace{\begin{array}{c}\text { PIA } \\ (\%, \text { by wt. })\end{array}}^{\text {Water-insoluble mucus }} & \begin{array}{c}\text { PIB/C } \\ (\%, \text { by wt. })\end{array} \\ \text { Hexose } & 27.7 & 27.2 & & 27.8 & 26.8 \\ \text { Hexosamine } & 28.6 & 27.2 & & 28.3 & 26.3 \\ \text { Fucose } & 13.0 & 10.5 & & 12.2 & 10.5 \\ \text { Protein } & 9.2 & 11.6 & & 8.4 & 10.3\end{array}$

region of the stomach and in this connexion it is noteworthy that the mannose-containing serum mucoproteins have been found in gastric secretions (Glass, 1965). In the pig cardiac preparation no radioactivity from $\left[\mathrm{U}-{ }^{14} \mathrm{C}\right]$ glucose was found in the amino acids, ribose, uronic acids or glucose, showing that no detectable incorporation of radioactivity had taken place into nucleic acids, acid mucopolysaccharides or glycogen. This is evidence of restricted utilization of glucose during the incubation in vitro of mucosal scrapings, although radioactive glucose was also metabolized by the respiratory enzymes of the cells, since ${ }^{14} \mathrm{CO}_{2}$ was released during the incubations. The absence of radioactive labelling in ribose and deoxyribose, together with the lack of effect of antibiotics on the incorporation of radioactivity into the non-diffusible material, showed that in these experiments no radioactivity was incorporated into bacterial material. The pathways by which glucose can be converted into galactose, fucose and hexosamines and the incorporation of the sugars from their nucleotide derivatives into mucoproteins have been well documented for other tissues (Ginsberg, 1964), including gastrointestinal mucosal tissues (Kent \& Allen, 1968; Race et al., 1968). Both [G- $\left.{ }^{3} \mathrm{H}\right]$ serine and $\left[\mathrm{G}-{ }^{3} \mathrm{H}\right]$ threonine were incorporated into the non-diffusible material by the scrapings in vitro. Whereas added $\left[\mathrm{G}-{ }^{3} \mathrm{H}\right]$ serine was incorporated into the non-diffusible material solely as serine, radioactivity from $\left[\mathrm{G}-{ }^{3} \mathrm{H}\right]$ threonine was incorporated into both threonine and glycine in approximately equal proportions. The $\left[\mathrm{G}-{ }^{3} \mathrm{H}\right]$ threonine used in these experiments was chromatographically pure, and amino acid analysis (Snary \& Allen, 1971) rules out the unlikely degradation of threonine to glycine during acid hydrolysis. It appears therefore that a metabolic pathway exists in pig gastric mucosal scrapings for the conversion of threonine into glycine. An enzyme capable of converting threonine into glycine, threonine aldolase, has been found in the liver and kidneys of a number of species (Braunstein \& Vilenkina, 1949).

Radioactivity was not incorporated from $\mathrm{Na}_{2}{ }^{35} \mathrm{SO}_{4}$ into the mucosal scrapings to a significant extent. This is notable because of the isolation from gastrointestinal tissue of sulphated mucoproteins, e.g. sheep colonic mucoprotein (Kent \& Marsden, 1963) and a dog stomach mucoprotein (Pamer et al., 1968), as well as the sulphated mucopolysaccharides isolated from pig stomach (Meyer et al., 1937; Kimura et al., 1964). The surface mucosal scrapings incorporated the largest amount of radioactivity from $\left[\mathrm{UL}^{14} \mathrm{C}\right]$ glucose into the non-diffusible material and had the highest $\mathrm{O}_{2}$ uptake and $\mathrm{CO}_{2}$ output of the different tissue sections (Table 3). The deeper tissue sections across the stomach wall did, however, incorporate significant amounts of radioactivity from $\mathrm{Na}_{2}{ }^{35} \mathrm{SO}_{4}$. The radioactivity from $\mathrm{Na}_{2}{ }^{35} \mathrm{SO}_{4}$ (1270d.p.m./mg dry wt.) incorporated into the mucosal sheet was shown to be present as ester sulphate, and no radioactivity was incorporated into the sulphur-containing amino acids. In keeping with these results are radioautographic studies, which have shown that the cells that incorporated $\mathrm{Na}_{2}{ }^{35} \mathrm{SO}_{4}$ were the mucous neck cells in the gastric glands and not the surface epithelial mucus-secreting cells (Cornet et al., 1964). The absence of $\mathrm{Na}_{2}{ }^{35} \mathrm{SO}_{4}$ incorporation by the surface mucosal scrapings shows that they did not contain significant amounts of the deeper secretory cells.

Since only $22 \%$ of the radioactive carbohydrate from $\left[\mathrm{U}-{ }^{14} \mathrm{C}\right.$ ]glucose and $22 \%$ of the radioactive protein from $\left[\mathrm{G}^{-}{ }^{3} \mathrm{H}\right]$ serine or $\left[\mathrm{G}-{ }^{3} \mathrm{H}\right]$ threonine was found to be water-soluble (Table 4), attempts were made to solubilize the radioactive water-insoluble mucus. The water-insoluble radioactivity was further solubilized by treatment with one or more different solvents (Table 5), but in no case was more than $80 \%$ of the total radioactivity solubilized. When mucosal scrapings, containing both ${ }^{14} \mathrm{C}$-labelled carbohydrate and ${ }^{3} \mathrm{H}$-labelled protein, were extracted with different

Vol. 127 
solvents, including water, the ${ }^{3} \mathrm{H} /{ }^{14} \mathrm{C}$ ratio in the different fractions was constant for one experiment. Thus the same percentage of the total radioactive carbohydrate and radioactive protein was soluble in each of the different solvents used. This suggests that the same spectrum of radioactive mucoproteins are solubilized by all the different solvents used and that the radioactive products in the insoluble non-diffusible material are closely related to the water-soluble radioactive material.

Since solvents were only partly successful in solubilizing all the water-insoluble radioactivity in the mucosal scrapings, enzymic methods were tried (Table 6). Various enzymic methods have been used to isolate mucoproteins from mucous secretions, e.g. pepsin digestion of pig stomach mucosa (Kabat, 1956), papain digestion of sheep colonic mucosa (Draper \& Kent, 1963) and dog stomach mucosa (Pamer et al., 1968), and ficin digestion of ovarian cysts (Pusztai \& Morgan, 1958). Pepsin digestion of pig mucosal scrapings from the cardiac region solubilized only $39 \%$ of the radioactivity from $\left[\mathrm{U}-{ }^{14} \mathrm{C}\right]-$ glucose. However, approx. $22 \%$ of this radioactivity would have been water-soluble anyway, so enzymic digestion was responsible for solubilizing only a further $17 \%$ of the total radioactivity. Skoryna \& Waldron-Edwards (1967) found that pepsin solubilized $20 \%$ of the carbohydrate of the insoluble mucus from human stomach. In contrast to pepsin, the three proteases ficin, papain and Pronase were very effective in solubilizing the radioactivity incorporated from $\left[\mathrm{U}-{ }^{14} \mathrm{C}\right.$ ]glucose into the water-insoluble material. Since Pronase was the most effective, $94 \%$ of the total radioactivity being solubilized, the Pronase-digestion products were studied further.

The products of Pronase digestion of the watersoluble mucus (fraction PS) and the water-insoluble mucus (fraction PI) were shown to be very similar. In both fractions PS and PI (Scheme 1), all the carbohydrate-positive material was excluded on Sephadex G-100 and had very similar blood-group $\mathrm{A}$ activities. Removal of the protein by $\mathrm{CsCl}$ densitygradient centrifugation gave a carbohydrate-containing fraction, which, on sedimentation analysis, was shown to possess two peaks of closely similar $s_{25 \text {,w }}$ values for fractions PS and PI, at two different mucoprotein concentrations (Table 7). Corresponding to these two boundaries observed by sedimentation analysis, two mucoprotein fractions, $A$ and $B / C$, were isolated by gel filtration on Sepharose 4B of the carbohydrate-containing fraction from the $\mathrm{CsCl}$ density-gradient centrifugation. The Pronase digests of the water-soluble and water-insoluble mucus gave identical profiles on Sepharose 4B after densitygradient fractionation, and the two mucoprotein fractions accounted for all the carbohydrate-containing material in the Pronase digests in each case (Fig. 2). The fractions PSA and PSB/C isolated from the water-soluble mucus and the fractions PIA and PIB/C isolated from the water-insoluble mucus (Scheme 1) had, within the limits of the analyses, identical fucose, hexosamine and hexose contents (Table 8). Similarly, the analysis of the protein content of all these fractions, as measured by the method of Lowry et al. (1951), is very similar, although nothing can be deduced about the composition of the different amino acids in the respective mucoprotein fractions. Also, this method has been shown to give low protein values for mucoproteins (Pamer et al., 1968). It has been suggested for human stomach that the water-soluble mucus is of similar carbohydrate composition to the waterinsoluble mucus (Schrager \& Oates, 1971).

Fractionation and characterization of the nondiffusible water-soluble fraction from pig cardiac scrapings has shown that all the radioactivity in ${ }^{14} \mathrm{C}$ labelled carbohydrate and ${ }^{3} \mathrm{H}$-labelled protein resides in one type of mucoprotein (Snary \& Allen, 1971). This mucoprotein, which comprises $84 \%$ of the watersoluble fraction, consists of two distinct fractions of different molecular weights $\left(1.9 \times 10^{6}\right.$ and $\left.1.1 \times 10^{5}\right)$, but both fractions have closely similar chemical and immunological properties (Snary et al., 1970). The identical patterns of radioactive material obtained from the solvent-extraction studies, and more particularly the identical nature of the mucoproteins released by Pronase digestion of the water-soluble and waterinsoluble mucus, indicate that the same mucoprotein type is in both fractions. These results also show that gastric scrapings in vitro are incorporating radioactivity from $\left[\mathrm{U}-{ }^{14} \mathrm{C}\right]$ glucose, $\left[\mathrm{G}-{ }^{3} \mathrm{H}\right]$ serine and [G${ }^{3} \mathrm{H}$ ]threonine into a single type of mucoprotein, which is the principal non-diffusible constituent of the water-soluble mucus, the only mucoprotein constituent of the water-insoluble mucus and, further, the only non-diffusible radioactive material produced by the gastric mucosa in vitro.

The reason why $22 \%$ of the radioactive mucoprotein is water-soluble whereas the remainder is in the water-insoluble gel is unknown. It is possible that all the mucoprotein was water-soluble but that a large percentage was made insoluble owing to interactions between the mucoprotein molecules or between the mucoprotein and other cellular material. Thus the water-insoluble radioactive mucoprotein when extracted with $2 \mathrm{M}-\mathrm{NaCl}, 0.2 \mathrm{M}$-mercaptoethanol or $8 \mathrm{M}$ urea was found to be water-soluble when the solvent was dialysed away. Further, the high-molecularweight component of the water-soluble mucoprotein will gel reversibly above $3 \mathrm{mg} / \mathrm{ml}$ (Snary et al., 1971). Alternatively, the mucoprotein may be made in vivo in an intrinsically insoluble form, which is partly or completely solubilized by proteolytic digestion or solvent extraction. Since solvents such as deoxycholate and urea, which are not known to break covalent bonds, solubilize a substantial part of the 
water-insoluble gel it would seem unlikely that covalent bonding is involved in gel formation.

We thank Mr. A. Robinson for excellent technical assistance and other members of the Department of Biochemistry for their help. We are also grateful to the Science Research Council for a Training Scholarship to D. S.

\section{References}

Allen, A. (1966) D. Phil. Thesis, University of Oxford Allen, A. \& Kent, P. W. (1968) Biochem. J. 106, 301 Ambler, R. P. (1963) Biochem. J. 89, 349

Braunstein, A. E. \& Vilenkina, G. Y. (1949) Dokl. Akad. Nauk SSSR 66, 243

Cornet, A., Bescol-Liversac, J. \& Guillam, C. (1964) Arch. Mal. App. Dig. Mal. Nutr. 53, 377

Creeth, J. M. \& Denborough, M. A. (1970) Biochem. J. 117, 879

Draper, P. \& Kent, P. W. (1963) Biochem. J. 86, 248

Fischer, F. G. \& Nebel, H. J. (1955) Hoppe-Seyler's Z. Physiol. Chem. 302, 10

Florey, H. W. (1962) Gastroenterology 43, 326

Gibbons, M. N. (1955) Analyst (London) 80, 268

Ginsberg, V. (1964) Advan. Enzymol. Relat. Subj. Biochem. 26, 35

Glass, G. B. J. (1965) In Gastric Secretion, Mechanism and Control (Shnitka, T. K., Gilbert, J. A. L. \& Harrison, R. C., eds.), p. 187, Pergamon Press, Oxford Herberg, R. J. (1960) Anal. Chem. 32, 42

Kabat, E. A. (1956) Blood Group Substances, p. 135, Academic Press, New York

Kabat, E. A. \& Bezer, A. E. (1945) J. Exp. Med. 82, 207

Kent, P. W. \& Allen, A. (1968) Biochem. J. 106, 645

Kent, P. W. \& Marsden, J. C. (1963) Biochem. J. 87, 38 P
Kimmel, J. R. \& Smith, E. L. (1954) J. Biol. Chem. 207, 515

Kimura, A., Watanabe, T. \& Nagai, Y. (1964) Fukushima J. Med. Sci. 11, 71

Lowry, O. H., Rosebrough, N. J., Farr, A. L. \& Randall, R. J. (1951) J. Biol. Chem. 193, 265

Ludoweig, J. \& Benmaman, J. D. (1967) Anal. Biochem. 19,80

Marcussen, J. M. (1970) In The Physiology of Gastric Secretion (Semb, L. S. \& Myren, J., eds.), p. 440, Universitets Forlaget, Oslo

Meyer, K., Smyth, E. M. \& Palmer, J. W. (1937) J. Biol. Chem. 119, 73

Pamer, T., Glass, G. B. J. \& Horowitz, M. I. (1968) Biochemistry 7, 3821

Pusztai, A. \& Morgan, W. T. J. (1958) Nature (London) 182, 648

Pusztai, A. \& Morgan, W. T. J. (1961) Biochem. J. 81, 639

Race, C., Ziderman, D. \& Watkins, W. M. (1968) Biochem. J. 107, 733

Schauer, V. R., Schoop, H. J. \& Faillard, H. (1968) Hoppe-Seyler's Z. Physiol. Chem. 349, 645

Schrager, J. \& Oates, M. D. G. (1971) Digestion 4, 1

Seifter, S., Dayton, S., Novic, B. \& Muntwyler, E. (1950) Arch. Biochem. 25, 191

Skoryna, S. C. \& Waldron-Edwards, D. (1967) Ann. N.Y. Acad. Sci. 140, 835

Snary, D. \& Allen, A. (1969) Biochem. J. 114, 85 P

Snary, D. \& Allen, A. (1971) Biochem. J. 123, 845

Snary, D., Allen, A. \& Pain, R. H. (1970) Biochem. Biophys. Res. Commun. 40, 844

Snary, D., Allen, A. \& Pain, R. H. (1971) Eur. J. Biochem. 24,183

Weimer, H. E. \& Moshin, J. R. (1953) Amer. Rev. Tuberc. 68, 594 